\title{
Some Irish Antiquities of Unknown Use
}

\author{
By E. C. R. Armstrong, F.S.A.
}

IN Sir William Wilde's Catalogue of Bronze Antiquities ${ }^{x}$ is described and illustrated under the heading of chariot furniture an iron-backed bronze disc, $3 \frac{3}{4}$ in. in diameter, coated with white metal, projecting from which is a bronze stud in the form of a dog's head, $I \frac{1}{2}$ in. long, with a human head engraved on its muzzle. The stud is threaded by a bronze chain made up of two rings and double loops (fig. I, I). Wilde considered this object was intended for the attachment of a trace. It was found when making a railway cutting near Navan Station adjoining the River Boyne in July 1848 , associated with a quantity of human remains; the skull of a horse; a number of antiquities including a bronze bridle-bit, and harness-plate; iron rings plated with bronze ; some small bronze buttons; and seven ornamented giltbronze plaques.

Wilde stated that the human bodies did not appear to have been placed in any order; in the surrounding earth was found a great quantity of charcoal extending from $2 \mathrm{ft}$. to Io $\mathrm{ft}$. below the surface. 'A small portion only of the grave, or battle-pit (if such it were), was traversed by the railway cutting, so that much of the ground of this very remarkable interment remains as yet unexplored '.2

The animal-headed boss, to which Wilde's figure does scant justice, remained an isolated specimen in the collection for some seventy years untilat the sale in 1920 of the antiquities preserved at Killua Castle an object of the same character was obtained ; details as to its discovery being unfortunately not recorded.

In its present state the Killua specimen consists of a bronze disc coated with white metal, to the sides of which were apparently attached ornaments of cut-out interlaced work of gilt-bronze ; of these one portion only remains. To this disc was fitted a movable bronze projection in the form of a horse's head; apparently this was also coated with white metal. The upper portion of the animal's face and its open mouth are gilt; the nostrils are marked by spirals; the eyes were filled with settings of blue

$$
\text { I 1861, p. 611. 2 Op. cit., pp. 573, } 574 .
$$


enamel. The pierced horse's head is threaded by a stout ring of bronze, which threads in turn a ring fixed to a plaque of bronze coated with white metal, engraved with lines and circles, and

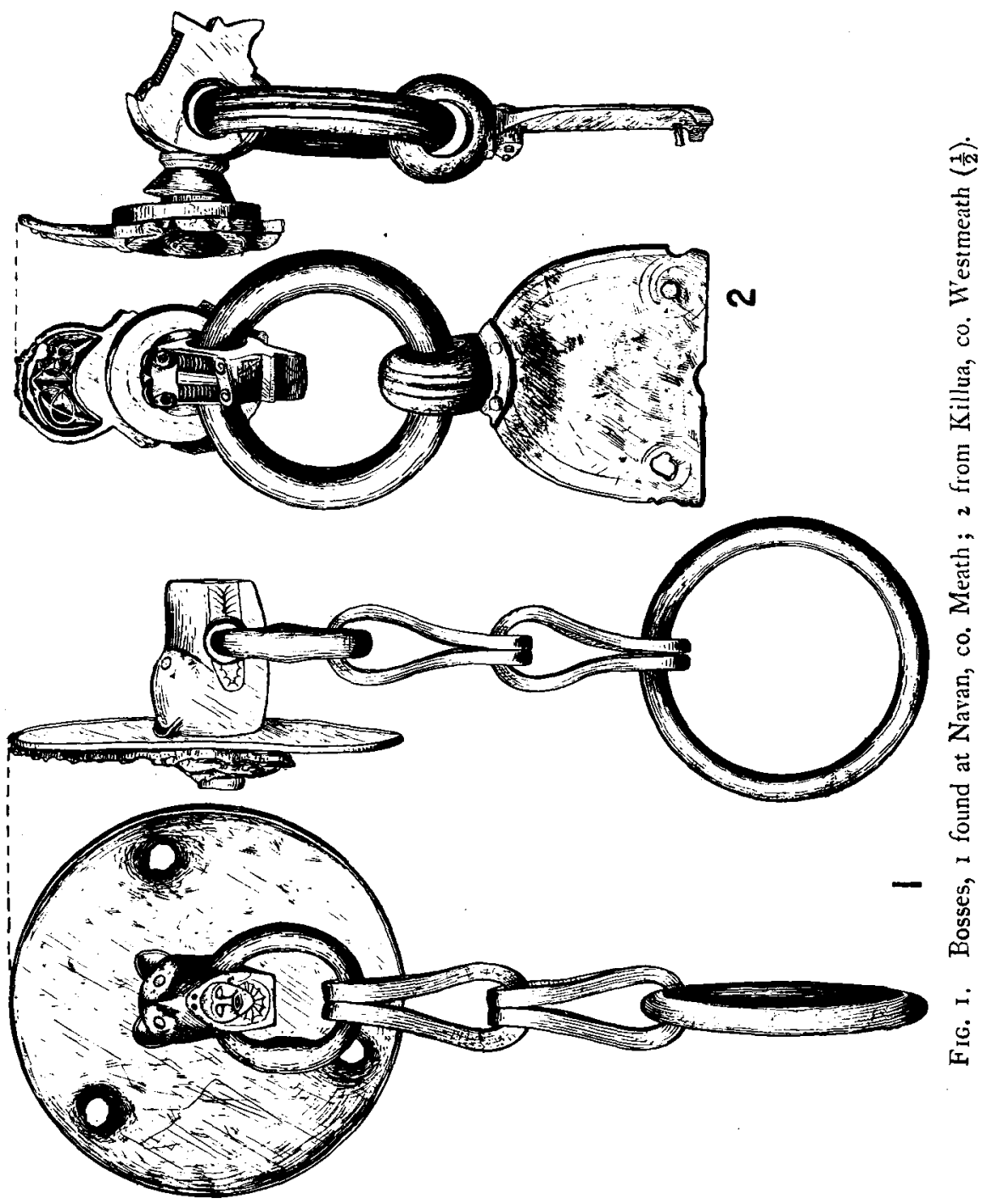

having rounded shoulders: this plaque had attachments for fastening it to some material (fig. I, 2).

The Navan boss has already been described in general terms; the illustration (fig. I, I) makes further details unnecessary. 
Attention may, however, be directed to a few points. 'The eyes of the animal are formed of red enamel; its teeth are indicated by lines; while the two nostrils placed close together make it apparent that the artist intended the head for that of a dog. The most curious feature is the human face engraved on the animal's muzzle. This is represented wearing a flounced collar, giving the face an appearance not unlike that of a 'pierrot'.

It is to be noted that whereas nothing is known to have been found with the Killua boss, its one remaining ornament of cutout gilt interlaced-work is of the same character as that on two of the seven gilt-bronze mountings found with the Navan boss. This furnishes an indication that the two objects are contemporary. What the original purpose of either may have been is not easy to determine.

The Navan find, fourteen objects belonging to which are preserved in the Royal Irish Academy's collection, has not been adequately published, for, as above stated, Wilde's figure of the boss is unsatisfactory. He illustrated three only of the seven gilt-bronze ornaments, the details of these not being in all respects correctly represented. ${ }^{\text {I }}$

Next to the boss the most interesting objects in the find are the seven gilt-bronze ornaments (pl. II); these were furnished at the back with eyes for attachment. One, according to Wilde, was cleaned by a jeweller : this both from its appearance, and by testing with a touchstone, is clearly copper rather than bronze.

As will be seen by the illustrations (pl. II), which are all made to the same scale (slightly below natural size, no. I measuring exactly $I \cdot 9$ in. across at the arms), two of these plaques are almost duplicates; these two with another (no. 4) show only interlaced decoration. Two are ornamented with spirals, as well as with zoomorphic ornament and interlaced work. The remaining two are decorated with zoomorphic and interlaced patterns. The workmanship of all is admirable.

A detailed description of each plaque is rendered unnecessary by the illustrations, but the zoomorphic ornament on nos. I, 3, and 5 may be remarked. On no. I it consists in the upper expanded limb of interlaced birds' necks, a design not unlike that to be seen on the silver brooch of Viking date found at Virginia, co. Cavan. ${ }^{2}$

The animals crouching with reversed head on the arms of no. 5 are similar ; the junction of their limbs is marked by spirals and in

I Three of Wilde's illustrations wese refigured with a drawing of the horse's bit in the Royal lrish Academy Celtic Cbristian Guide, 1910.

2 Coffey, Royal Irish Academy Celtic Christian Guide, pl. iv, I. 


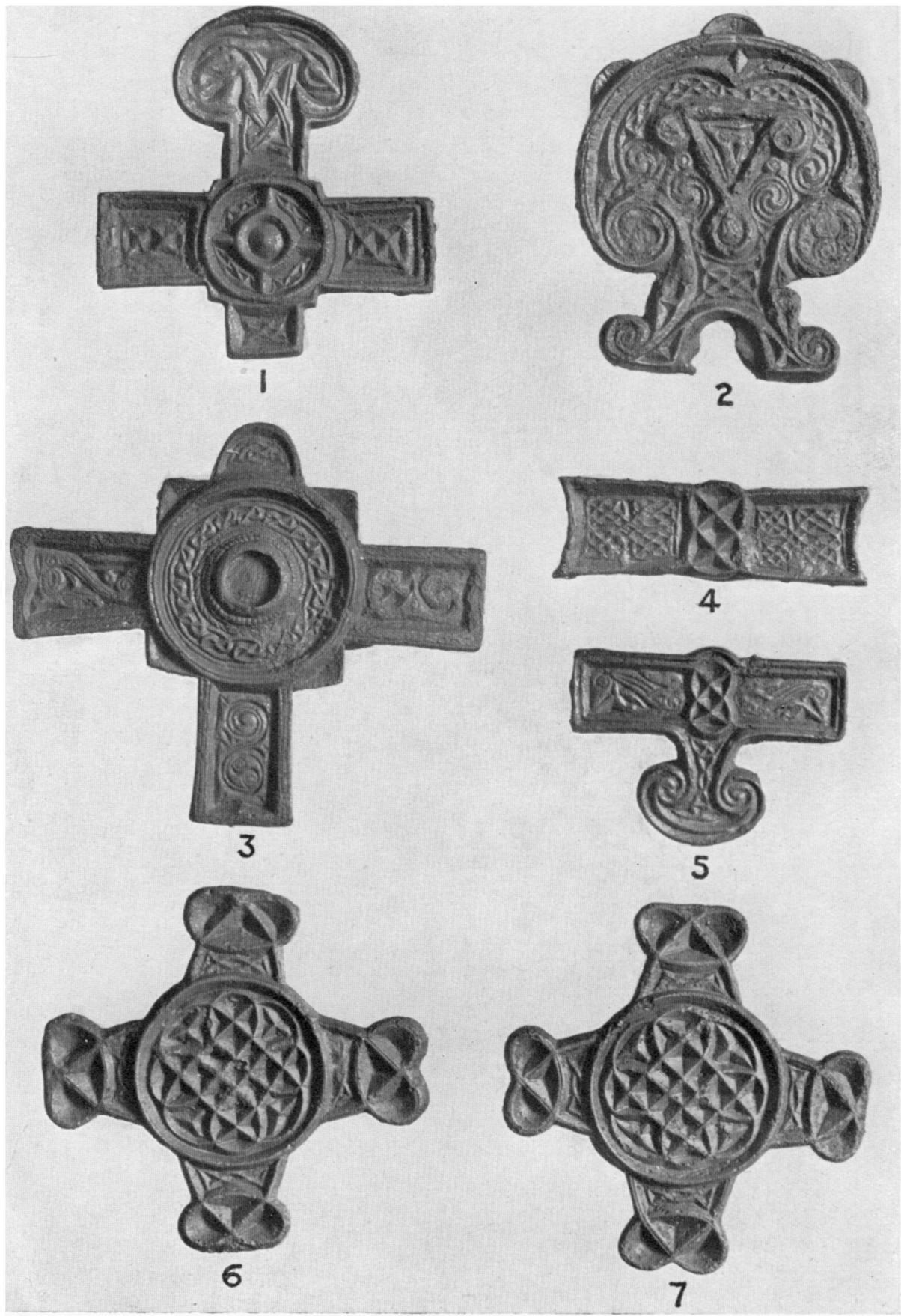

Plaques of Copper or Bronze, Gilt, found at Navan, Co. Meath (slightly below natural size) 
general outline they resemble that on the dexter arm of no. 3 (shown reversed on the plate). The bird-necked zoomorph in the centre of plaque no. 2 bears a resemblance to that on the pin-head of one of the Ardagh brooches. ${ }^{x}$

A crouching animal looking 'backwards, a useful design for filling a rectangular space, is not infrequently found on Irish metal work; it may be observed upon the back of the Killua Shrine. ${ }^{2}$ It may be noted that Salin, who considers two of the chief styles of Irish ornament as adapted from the German, i.e. the geometrical and the zoomorphic, considers the crouching animal with turned head when found in Irish ornamentation to be indicative of German influence. ${ }^{3}$ The relationship between Irish and Germanic zoomorphic ornament being of a complicated character, it would appear safer to regard both as derived from the same source, rather than to consider the Irish as adapted from the latter. In this connexion Mr. O. M. Dalton's Byzantine Art and Archaeology may be profitably studied (pp. 25-27).

The finding of the objects at Navan associated with the skull of a horse, a horse's bit, and the boss, caused Wilde to consider that a chariot had formed part of the interment. But no remains of this appear to have been found.

It is, however, to be noted that Rygh ${ }^{4}$ has figured a number of gilt-bronze plaques found in Norway which closely resemble those found at Navan. Rygh describes these as being of Irish style, worked either in Ireland or in Scotland, ${ }^{5}$ or England, after the penetration of the Irish style to those localities. Ten such plaques were found at Some, Høiland, Stavanger, with a horse's bit of iron, an oval bronze brooch, some rings, etc. Another was found with a piece of a sword, or of a lance-head, and an iron ring possibly from a horse's bit. Therefore, it seems there is some reason for considering that such ornamental plaques as those found at Navan were used for the decoration of horse furniture.

The large boss present in the Navan find, considered by Wilde as the attachment of a trace, may well have been attached to a vehicle of some kind, for it is difficult to imagine to what portion of the actual harness of a horse it could have belonged.

The term chariot used by Wilde calls to mind the classical type with small wheels and a body close on the ground, drawn by

I Smith, Archaeologia, lxv, p. 243.

2 Antiquaries Journal, I, pl. v.

3 Altgermanische Tierornamentik, pp. 342, 343.

4 Norske Oldsager, figs. 618-27, see also pp. 32 and 76 .

5 Two bronze-gilt mountings of this type found in Perthshire are illustrated in the Catalogue of the National Museum of Antiquities of Scotland, 1892, p. $20 \mathrm{I}$. 
a pair of horses. That chariots presumably of this type were in use in Ireland in the La Tène period seems clear from the descriptions in the $\mathcal{T}$ din $B$ b Culalnge. ${ }^{x}$ For the vehicles in use in the early Christian period we have little evidence. What is available is to be found carved on the base of the High Cross of Muiredach, at Monasterboice, co. Louth; on the base of the east face of the cross of King Flann at Clonmacnois, King's County; the South Cross, Kells, co. Meath; the North Cross at Ahenny, co. Tipperary; and the right arm of the west face of the Cross at Killamery, co. Kilkenny.

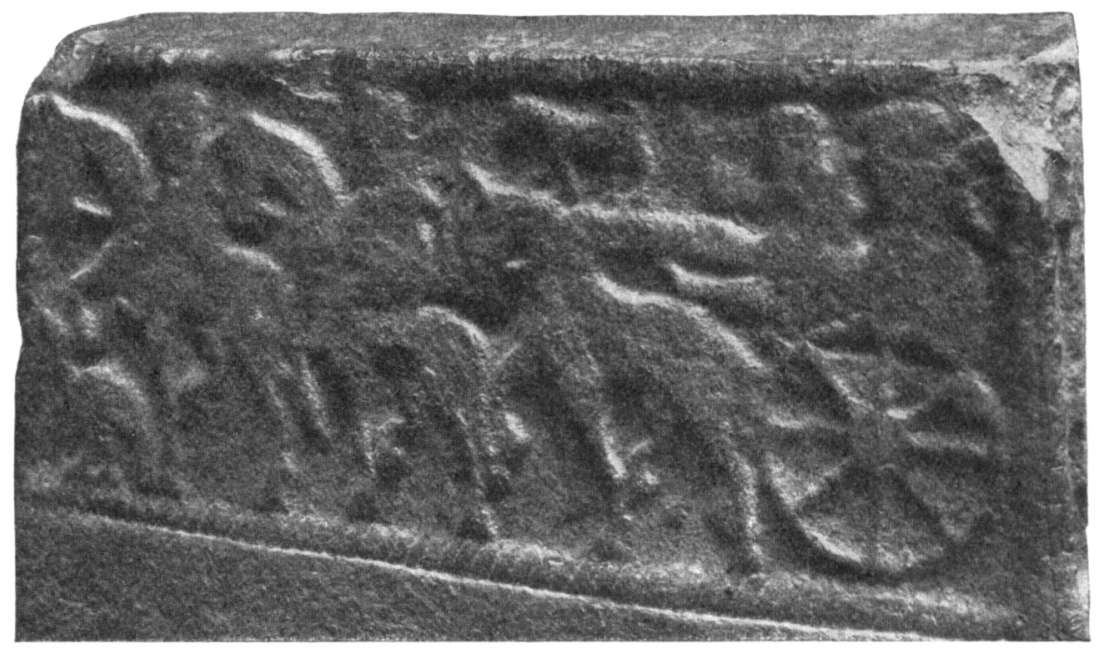

Frg. 2. Panel from North Cross at Ahenny, co. Tipperary.

The bases of Muiredach's cross, of King Flann's cross, and of the Kells Cross, are much worn : it is difficult to make out the details of the vehicles represented; but they differ from the classical examples in having wheels of a larger diameter. Professor R. A. S. Macalister's drawing of the first, ${ }^{2}$ and Mr. T. J. Westropp's of the second, ${ }^{3}$ may be examined. Mr. Westropp, who remarks that the carvings on the Clonmarnois cross are weathered, and that Petrie's view of the cross seems to be idealized, adds that the north chariot has a boat-shaped back and a ninespoked wheel. Better preserved is the base of the Ahenny cross; as can be seen from the illustration (fig. 2) two horses are shown,

- See Windisch, Táin Bó Cúalnge, I 905 , introduction, pp. xii-xv.

2 Muiredach, p. 69.

3 Journal Royal Society of Antiquaries of Ireland, xxxvii, fig. on p. 294, description on p. 292. See also Petrie, Christian Inscriptions, i, pl. xxxiii. 


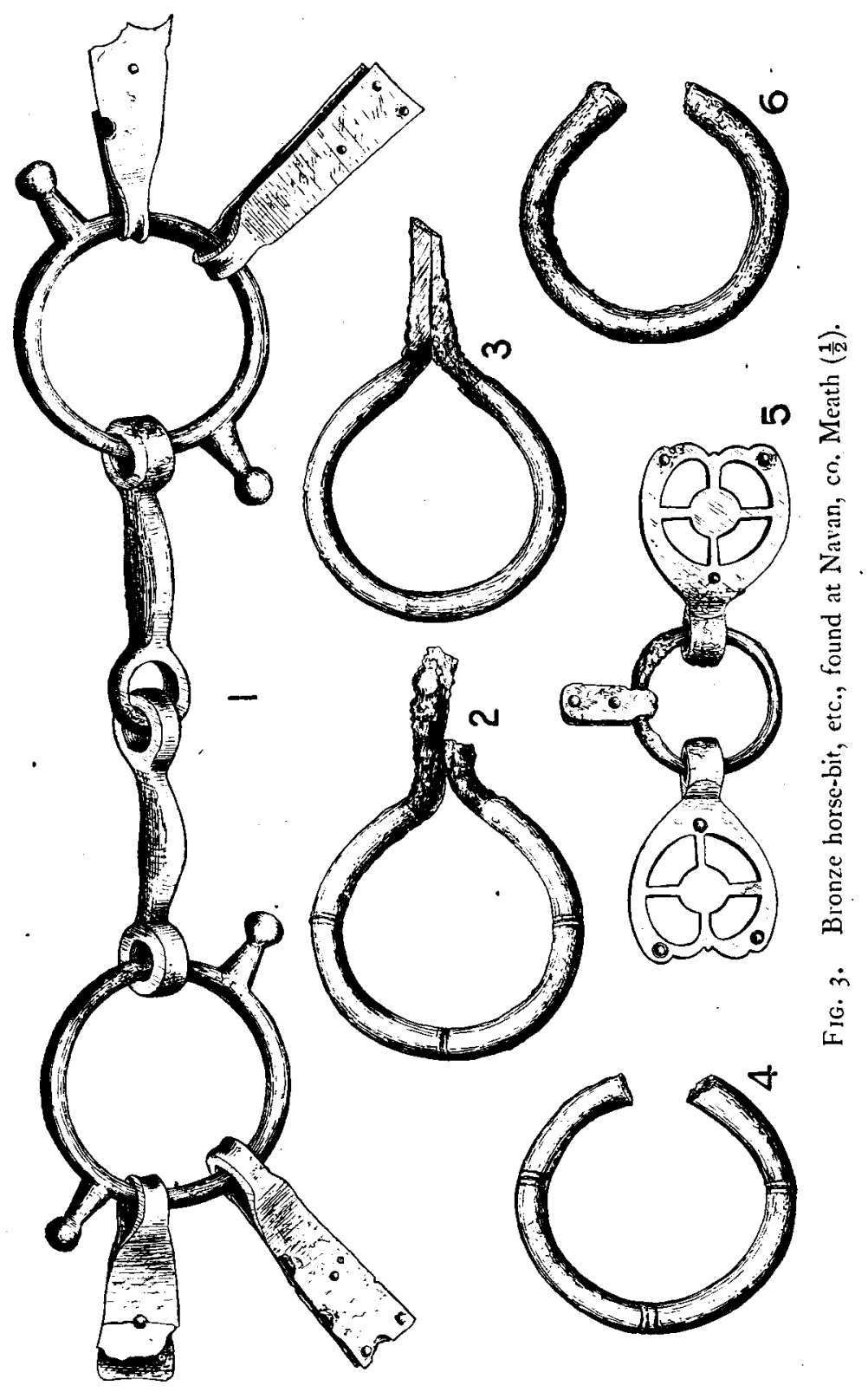


while the body of the car appears to be flat, the occupants having their legs stretched out over the horses' backs.

The remaining objects (fig. 3 ) of the find include the horse's bit which is made of bronze : it is an ordinary snaffle with stops on the rings, to each of which are attached rein-tangs : another bronze object consists of a ring which threads two similar open-work plates and a small tang; the two open-work plates have attachments at the back for fastening them on to some material, probably a strap of leather. The four rings are made of a core of iron coated with bronze; two of them have staples by which they could have been driven into a wooden bar. Possibly they were used for the attachment of traces. One is slightly ornamented. The other two rings, one of which is ornamented, are penannular.

On the whole it seems probable that the Navan boss and rings were attached to a vehicle, while the specimen from Killua also may have been similarly attached. It is, however, not so easy to form an idea of its use, for unlike the Navan boss with its ring, which could be conveniently used, the Killua boss has an attached plate ; this may, however, have been fastened to a leather strap.

To date the Killua boss and the various objects belonging to the Navan find is a matter of some difficulty. Coffey, who devoted a few lines to the find, wrote 'the trumpet pattern on some of them places the objects probably before the tenth century'.

The similarity of the zoomorph on one plaque (pl. II, no. 2) to those on the pin head of one of the Ardagh brooches and of the interlaced birds' necks on another (pl. II, no. I) with those on the Virginia brooch has been mentioned. A suggested date for the first brooch is the middle of the ninth century, for the second the middle of the tenth. ${ }^{2}$ At this period the influence of the Vikings had begun to make itself felt in Ireland, in which connexion it is perhaps worth while remarking that the horse's head on the Killua boss shows a resemblance to the animal-headed weight found in the Norse cemetery at Island-Bridge, ${ }^{3}$ in both cases the nose being ridged and the nostrils decorated with spirals.

The spiral attachments of the limbs of the animals on two of the plaques (pl. II, nos. 3 and 5) show that in any case these objects are not earlier than the eighth century A.D. ${ }^{4}$ But the excellence of their workmanship gives little indication of the period of decay. Therefore, the late ninth or early tenth century may be suggested as a probable date for both the Killua boss and the Navan find.

1 Royal Irish Academy Celtic Christian Guide, 1910, p. 71.

2 Smith, Archaeologia, lxv, pp. $249,250$.

3 Proc. Royal Irish Academy, Coffey and Aimstrong, xxviii, sec. C, p. I 19.

4 See Altgermanische Tierornamentik, pp. 343, 344, and 357. 